\title{
Practice of Improving Young Teachers' Engineering Ability in Application-Oriented Universities
}

\author{
YuFeng $\mathrm{Lu}$ \\ School of Mechanical and Automotive Engineering \\ QILU University of Technology \\ Jinan, China \\ luyf78@126.com
}

\begin{abstract}
There are more and more young teachers in the higher school. But most of them come directly from colleges and universities and their engineering practice ability is insufficient. In order to training students' ability of engineering practice young teachers' ability of engineering practice must be improved first. Based on the actual of our school three pathways to improve young teachers' practical ability are put forward. First, young teachers may participate in vocational skills competition to improve practical ability. Second, they may guide students of science and technology competition to improve the teaching ability of them in engineering. Third, participate in enterprise where young teachers may do some practical engineers to exercise their engineering thinking. The practical ability of young teachers is enhanced significantly through the combination of the three forms' exercise.
\end{abstract}

Keywords_young teachers; engineering practice; science and technology competition; vocational skills

\section{INTRODUCTION}

The Ministry of Education advocates the promotion of "excellent engineer education and training program" in institutions of higher learning. The key to the implementation of this plan is to have a team of teachers with both theoretical knowledge and engineering experience. Comrade Deng Xiaoping once pointed out: "can a school or not for the construction of socialist culture qualified talent, cultivate allround development, cultural workers with both socialist consciousness, the key lies in the teachers." At present, there are many young teachers and most of them are from school to school teaching, lack of practical experience in engineering design, construction management and other aspects. Therefore, only to improve the engineering practice ability of young teachers can cultivate students' engineering practice ability. Teachers' engineering practice ability refers to the special quality and ability of the teachers in the implementation of the engineering education which is oriented to the production practice[1]

That is to say the ability of engineering practice is not a single kind of ability but is a variety of engineering ability of the composition of the comprehensive ability, specific performance for several aspects. First, the ability is actual operating capacity. Actual operation ability refers to according to certain norms, procedures and requirements for the actual operation ability, including equipment operation, product manufacture and so on. This is the basic ability application college young teachers should have. Two is the engineering teaching ability. To nurture teaching is the ultimate goal of young teachers in application type undergraduate colleges to improve engineering practice ability. They should know how to teach students in engineering practice, such as engineer case, background knowledge and operating skills. Three is the quality of engineer thinking. Only teachers with a good quality of engineer thinking in the teaching process can cultivate students' engineering thinking quality and thinking habits.

\section{THE NECESSITY OF IMPROVING THE ENGINEERING PRACTICE ABILITY OF YOUNG TEACHERS}

Application type undergraduate colleges and universities are accompanied by mass higher education and adapt to the needs of economic and social development came into being. It is a new type higher education of colleges and universities. The essential characteristics are the local, practical, technical and practical[2]. Therefore talents training mode and the construction of teachers should have their own laws and unique requirements but there is no mature model at present. We need to be in the practice of continuous exploration and theoretical research. The teacher is the main body of the school and the teacher's ability construction is the core of the construction of the teacher team. Therefore, ability construction of applied undergraduate colleges' teachers should fully adapt to the application type talents training mode reform. It should be in accordance with its type location around the feature of application requirements, in a prominent strengthen practice ability. This is the trend and the urgent task for ApplicationOriented universities to deep the reform of education and teaching[3].

Higher engineering education should cultivate students' practical ability, entrepreneurial ability and innovation ability which are the comprehensive reflection of the quality of higher engineering education. Practical teaching is an important means to cultivate and improve students' abilities. Now the situation is teachers are lack of innovation and practical ability which seriously affect the practice of teaching reform of new undergraduate colleges. So the improvement of teachers' practical ability and comprehensive quality has become a pressing matter of these schools at the moment.

Most of the applied undergraduate colleges are transformed from teaching or teaching research universities at present. The 
ability of the teacher is still stuck in the traditional idea and the standard of the past. The school put too much emphasis on theory teaching and scientific research ability. There is not enough attention to the construction of teachers' practical ability. China's strategic will transform from a large population to a country rich in human resources and will improve the comprehensive competitiveness of the country so innovative ability and practical ability is a key indicator. Young teachers play an important role in this transformation. Therefore, promoting the development of local economy and society can not be separated from the improvement of the practical ability of young teachers.

The practical ability of the graduates of local colleges and universities is poor which reflects the ability of young teachers is poor too in this area. A young teacher who has theoretical knowledge only is unable to cultivate the innovative spirit and practical ability of high quality students if he is lack of practical experience. Therefore, the young teachers' practical ability and the employment of college students are closely linked from the point of view of improving the employability of graduates to strengthen the comprehensive quality of young teachers.

\section{PRESENT SITUATION OF YOUNG TEACHERS' ENGINEERING PRACTICE ABILITY}

The majority of young teachers in colleges and universities have grown up under the traditional education mode which has the characteristics of high educational level and rich theoretical knowledge [4]. The biggest weakness of young teachers lies in the lack of practical ability. The vast majority of young teachers in local colleges and universities have graduate or above, they have a solid theoretical knowledge, but lack of practical experience and lack of scientific research ability, it is difficult for them to achieve academic independence.

The concept of talent training in Applied Undergraduate Colleges and universities is not enough; only pay attention to the teaching of the theoretical knowledge of the subject, the research is not deep. Young teachers' teaching task is very arduous. This makes it hard for them to put too much energy into engineering practice. Coupled with the lack of effective management system and a clear assessment objective between the enterprise and the school. This leads to the young teachers to participate in the engineering practice of the enterprise floating on the surface. So these activities did not substantially improve the engineering practice ability[1].

The student teacher ratio is relatively high in our school at present so the teachers' teaching task is very heavy. New teachers should take 2 3 courses each semester by task. In addition to bear the corresponding experiment, practice, and guide the teaching of graduation design and other practical courses. In addition, new recruits will participate in the school's performance evaluation from the second years. New teachers in the completion of the corresponding teaching tasks at the same time they will complete a certain scientific research (teaching and research) tasks. So they don't have enough time for engineering practice. This requires young teachers in the completion of the evaluation tasks at the same time to improve the ability of engineering practice. So we put forward a way to improve teachers' engineering practice ability based on the fact of our school practice. Through these ways the young teachers can complete their performance evaluation and improve their engineering practice ability at the same time.

\section{METHOD OF IMPROVING PRACTICAL ABILITY OF ENGINEERING}

Combined with the characteristics of most of the Application-Oriented undergraduate institutions and our school's related evaluation policies the engineering practice ability of young teachers can be improved from the following three aspects.

\section{A. Combined With Vocational Skills Competition To Improve Practical Ability}

Teachers not only to teach the basic theory of the course but also the contents of the course of the application of practical guidance and combined with specific cases to carry out the operation of the exercise. This is like a car coach. First of all, he should know the car structure and basic operation principle. On this basis he must also have excellent driving skills but also have the skills to teach to others. Without the ability to teach he will not be able to become a qualified coach. Constantly improve the practice and innovation ability of engineering education young teachers in colleges and universities may train more high-quality, high level of engineering applied talents [4].

Professional skill competition has important effect on the cultivation of young teachers' professional practice ability. Our school provides young teachers facilitating to participate in national, provincial and municipal level industry associations and other levels of various types of vocational skills competition. After they win the competition the corresponding assessment scores can be obtained to complete their performance evaluation[5]. For example, the school provides teachers to participate in a variety of competitive activities can be rewarded with a certain score. In the performance evaluation can be arrived at the corresponding teaching and scientific research scores. This provides protection for teachers to participate in vocational skills competitions. For example, they may participate in the contest of multimedia courseware, engineering application technology teachers contest and other competitions which teachers as the main body to participate.

Educational information brings profound changes in educational philosophy and teaching mode which is the only way to promote educational equity and to construct a learning society. The rapid development of information technology promotes the development and application of digital educational resources. Making full use of information technology teaching means to improve teaching methods and teaching quality has become the inevitable trend of the development of modern educational technology. In order to fully excavate the excellent courseware achievements of each teaching unit, and to improve the application level of teachers' educational technology, the experience and experience in the production of multimedia courseware are discussed and discussed.

College engineering application technology teachers contest is also focused on improving the ability of teachers to 
practice a national tournament. In line with the purpose of improving the teacher's in colleges and universities engineering skills competition is carried out for the current status of young teachers. Through the development of skills competition the teachers' experience in engineering practice can be enhanced so that teachers adhere to the direction of engineering technology application. This will meet the requirements of excellent engineers and the application of technical personnel training. Technical competition was carried out widely in the scope of engineering technology and skills competition's main content of the project was the technical field of modern manufacturing, new energy, environment and automation systems, electronic information and electrical engineering etc.. Engineering technology competition's purpose is to promote design innovation and application of innovation. Its purpose is to promote the development of a new generation of both theory and practice of the "excellent engineer" teachers. Through these technology competition we will improve the training quality of engineering and technical personnel in colleges and universities.

By taking part in all kinds of competitions young teachers can discover the advantages and disadvantages of their own and their peers. To participate in the competition to avoid weaknesses and improve personal hands-on skills. Through taking part in the competition it also promotes the teacher's knowledge updating which enriches the teaching case after the day in the course of teaching.

\section{B. Guiding Students' Science And Technology Competition To Improve Engineering Teaching Ability}

Application based curriculum teachers should be good at transforming practical experience into classroom teaching. Teachers' ability to guide practice is important but we can not forget the teacher's own job. Teachers are not the commanders on the battlefield but he need to teach the skills to win the battles. Therefore, the application of teaching teachers, teachers must be good at the successful experience in practice, the organic integration into the classroom teaching, so that students learn to benefit from the use of. In this, we must guide and encourage students to "go out of the classroom, face the reality". Teachers should let students understand and master knowledge not for the completion of work and obtained a good achievement in the subject, but should put in practice application set as the first, clear grasp the knowledge not to "test" but for "use". The change of the concept and consciousness is very important to the cultivation of applied talents. In the application of case teaching and improve students' ability at the same time, there is a very important content is to encourage students to innovate, to "out of the blue and" the pursuit of[5].

It is helpful for young teachers to establish a comprehensive knowledge system and improve the ability of comprehensive design. In order to make students' creative activities become a kind of teaching activities with planned and organized activities, at the same time, it can meet the different requirements of different levels of students. For young teachers, this process is a refresher, check the lack of trap in the learning process, not only the original professional knowledge system, also students together on the related knowledge of mechanical design and program control of supplement and the study. Therefore, guiding students to participate in innovation and competition can cultivate young teachers mechanical and electrical system integrated design capabilities, broaden their knowledge, improve their theoretical level and practical ability [6].

Help young teachers to improve the ability to analyze and solve problems. In order to make the students' creative activities become a kind of teaching activities with planned and organized activities. At the same time, it can meet the different requirements of different levels of students on innovative teaching. For the youth teacher, this process is a new learning process, find deficiencies. This process not only makes the teacher's original professional basic knowledge. And students together with the mechanical design, program control and other related knowledge to complement and learn. It stimulates the driving force to guide teachers to think, learn and practice. It is helpful to guide the cultivation of creative thinking and improve the ability of innovation.

Application-Oriented curriculum teachers should have a strong ability to guide practice. For the guidance of all kinds of competition, if the guidance of teachers has a wide range of knowledge and rich practical experience, to guide it will be handy [7]. But for some of the new office of young teachers, knowledge can not be proficient in the face. Lack of knowledge in individual areas. They also lack experience in the overall system design and engineering practice. This is one of the main reasons why many young teachers are afraid to participate in various competitions. Our school teachers often guide students to participate in Shandong Province, mechanical and electrical product design contest the national robot competition, etc.. When directing the competition, we need to select the players, make the parameter plan, and organize the training, the rules of interpretation, the new knowledge study, the production of the work. Each link allows the instructor to benefit a lot. Not only the practical ability has been improved, teaching ability, communication ability and other multi and ability to achieve a qualitative leap.

\section{Participate In Enterprise Practice Training Engineering Thinking Ability}

The cultivation of applied undergraduate students is a systematic project which is a whole project of teachers and students. Only the school teachers are aware that "how to cultivate applied talents" and the industry is aware that "how to participate in training applied talents" as a subject and the students are aware that "how to become talents". This need school teachers, enterprises, students to participate in to truly cultivate the "Pro industry" of the engineering and technical personnel. This will form a real applied talent training concept.

Application-Oriented personnel training should be an open and cross-border, close to the industry's education system, should be located to meet the needs of the industry[8]. Only the establishment of the school and industry multi linkage operation platform. Through the innovation of the industry synergy education mechanism, using the three dimensional promotion as the implementation means, the talent training is placed in the open system of multi participation by the industry 
sector. Through the whole process of teaching, production practice, innovative $\mathrm{R} \& \mathrm{D}$ and application services, we can adapt to the new requirements of the economic development mode to the talent training.

Collaborative innovation between universities and enterprises is not only the social responsibility to meet the requirements of the development of the times, but also the internal demand of promoting the development of the university itself. This is another challenge and opportunity faced by our university and enterprise in the personnel training. School enterprise collaborative innovation is the innovation of the main body of University, enterprise and government departments, around the same goal, to carry out deep, diverse cooperation and exchange, and thus produce more innovative results of the process. In the past, the school enterprise cooperation, generally refers to the cooperation of scientific research projects, people think more of the project funding issues. But colleges and universities are the base of the national talent cultivation. So school enterprise collaborative innovation should be the depth of cooperation between universities and enterprises in the aspects of personnel training, cooperative research, team building, and platform construction and so on. School enterprise cooperation to solve the core issues facing the development of the industry. Not only to enhance the core competitiveness of enterprises, but also to enhance the level of academic and personnel training. In order to realize the seamless connection between the training of the school and the production practice of the enterprise. Engineering colleges should plan to arrange young teachers first-line enterprises attachment to participate in engineering practice, rather than as a practice to visit and study, only in this way can we let young teachers as much as possible in the actual problem processing, rich practical experience, an increase of practical skills. Through school enterprise cooperation, encourage young teachers in the rich experience of the old teachers, driven by the project as a driver; actively participate in the enterprise's key projects. To promote the transformation of scientific research achievements into productive forces. And participate in the project practice project at the same time, expand the project field of vision, enhance the ability of the team cooperation.

It is an important form of teacher on-the-job training to organize teachers to enterprise practice, and it is an effective way to improve teachers' professional skills and practical teaching ability. This is also an urgent need to strengthen the construction of teaching staff, but also a close relationship with the enterprise, strengthen the specific embodiment of the school enterprise cooperation. This will have a very positive significance for the promotion of education and teaching reform and the transformation of the mode of personnel training. Young teachers in-depth business can understanding of enterprise production organization, process, industry trends and other basic situation, familiar with enterprise related jobs (jobs) responsibilities, and operating norms, with the specific content of the standard and management system. In the process of participating in the enterprise engineering project, the engineering thinking quality of teachers can be exercised. By studying the new knowledge, new skills, new technology and new methods of production practice; the teaching plan can be improved continuously. Developing practical skills innovation courses and improving the quality of applied talents training.

\section{CONCLUSION}

Training of engineering practice ability of young teachers in higher engineering college is a great event that concerns China's higher engineering education for sustainable development. Strengthening the training of young teachers' practical ability can promote the improvement of their comprehensive quality. And this can promote the development of local economy. Young teachers should recognize the teaching, cultivating useful talent is their unshirkable responsibility to sober their own weaknesses, to overcome the lack of practical experience. Adhere to the theory with the actual teaching style, from the teaching practice and social practice to enhance the theoretical height. But it's a systematic project that needs cooperative combat between governments; enterprise, school and young teachers, and its operation mechanism need further research.

\section{ACKNOWLEDGMENT}

The results of this study are funded by Postgraduate Education Innovation Program of Shandong Province(SDYY14025).

\section{REFERENCES}

[1] Zhang Yong, "Research on engineering practice ability training of young teachers in Applied Undergraduate Colleges," China Adult Education, vol.9, pp. 72-74, 2013.

[2] Wei WeiLian, Xie ChuanHui, "Teaching reform practice of human resource management course in Applied Universities, "Journal of Anhui Science and Technology University, vol.2,pp. 93-97, 2013.

[3] Wei WeiLian, "Research on the construction of practical ability of teachers in Applied Undergraduate Colleges, "Global Education Outlook, vol. 5, pp. 43-52, 2015.

[4] Li Yi, " Teachers' innovation and practical ability cultivation of Applied Talents in the research of," Qiu Shi, vol. S2, pp. 267-268, 2012.

[5] Zhang Xiping, Zhang Jianhua, “ An analysis of the professional practice ability of young teachers in Colleges and universities of three, "Teachers Education Forum, vol. 4, pp. 40-43, 2013.

[6] Wang Yuhong, Zhang Guojun, Ma Yufang, "Guide science and technology competition to improve the practical ability of young college teachers, "Higher Education Forum, vol. 5,pp. 61-63, 2012.

[7] Safhalter, Andrej, Vukman, Karin Bakracevic, and Glodez, Srecko, "The Effect of 3D-Modeling Training on Students' Spatial Reasoning Relative to Gender and Grade," Journal Of Educational Computing Research,vol.54, pp. 395-406,2016.

[8] Braghirolli, Lynceo Falavigna; Duarte Ribeiro, Jose Luis; Weise, Andreas Dittmar, "Benefits of educational games as an introductory activity in industrial engineering education, " Computers In Human Behavior, vol. 58. pp.315-324, 2016 